\title{
Influence of Nitrogen Source on the Catabolism of Naphthalene by a Pseudomonas aeruginosa TU
}

\author{
K.R. Savitha ${ }^{1}$, T.N. Shamu ${ }^{1}$, Lalitha Junna ${ }^{2}$ and Manohar Shinde ${ }^{1 *}$ \\ ${ }^{1}$ Department of Studies and Research in Biochemistry, Tumkur University, \\ Tumakuru-572103, Karnataka, India \\ ${ }^{2}$ Department of Biochemistry, Gulbarga University, Kalaburagi-585106, Karnataka, India \\ *Corresponding author
}

\section{A B S T R A C T}

\section{Keywords}

Pseudomonas aeruginosa $\mathrm{TU}$, Nitrogen source, Naphthalenedegrading enzyme

Article Info

Accepted:

10 September 2019

Available Online:

10 October 2019
A Pseudomonas aeruginosa TU isolated from diesel-contaminated site degraded $66 \%$ of an initial $10 \mathrm{mM}$ naphthalene load after $48 \mathrm{~h}$ of incubation in a minimal-salts medium containing $\mathrm{NH}_{4} \mathrm{Cl}$ as nitrogen source whereas, the same bacterium, when incubated in the minimal-salts medium containing $\mathrm{KNO}_{3}$, degraded 10 and $20 \mathrm{mM}$ initial naphthalene load within in 24 and $36 \mathrm{~h}$ respectively. The naphthalene enrichment medium containing $\mathrm{NH}_{4}^{+}$ as nitrogen source slowed bacterial growth and compromised cell viability over $72 \mathrm{~h}$ while, naphthalene-minimal salts medium when supplemented by $\mathrm{NO}_{3}{ }^{-}$showed uniform and efficient cell growth. The bacterial degradation of naphthalene in the minimal-salts medium containing $\mathrm{KNO}_{3}$ resulted in transient accumulation of salicylate $(0.11 \mathrm{mM})$ and catechol $(102 \mu \mathrm{M})$ after 12 and $24 \mathrm{~h}$ respectively whereas, in the medium containing $\mathrm{NH}_{4} \mathrm{Cl}$, the naphthalene biodegradation caused decrease in the $\mathrm{pH}$ of culture medium from 7 to 3.8 and accumulation of $0.63 \mathrm{mM}$ salicylate and $24 \mu \mathrm{M}$ catechol as dead end products. Further, the cell-free extracts of the bacterium grown on naphthalene in the medium containing $\mathrm{KNO}_{3}$ showed high activities of naphthalene-degrading enzyme as compared to that of the cell-free extracts of bacterium grown on naphthalene and $\mathrm{NH}_{4} \mathrm{Cl}$.

\section{Introduction}

Polycyclic aromatic hydrocarbons (PAHs) are of natural and anthropogenic origin, are the compounds of human health and environmental concern due to their toxic, mutagenic and carcinogenic properties (Menzei et al., 1992). Due to their calcitrant and highly persistent nature they are often found to bioaccumulate in aquatic organisms (Lotufo, 1998). Even though, PAHs are highly hydrophobic and persistent chemicals, reports of their degradation by variety of microorganisms are available like, Cerneglia (1993), Sutherland et al., (1995), Manohar and Karegoudar (1999), Daane et al., (2001), Bamforth and Singleton (2005). Human exposure to PAHs may occur due to incomplete combustion of fossil fuel, accidental discharge into aquatic and terrestrial environments during transport use and disposal of petroleum products, coal 
gastification and liquification process and through industrial effluents (Laflame and Hites, 1978, Paterson and Kodukala, 1981, Jacob et al., 1986). Naphthalene, being the simplest homologue in the polycyclic series, has received considerable attention because, the knowledge on bacterial degradation of naphthalene has been valuable for understanding the fate of naphthalene in the environment and also to understand the pathways used for the degradation of more complex PAHs (Sutherland et al., 1995, Mahohar and Karegoudar, 1995).

Naphthalene a possible carcinogen (IARC, US-EPA, Gervais et al., 2010) is one of the important industrial and house hold chemical. Two-third of the global production of naphthalene was consumed in the production of phthalic anhydride, which is in turn used as starting material for synthesis of various industrial chemicals and also as plasticizer, pesticides and cleaner formulations. It is used in the manufacture of synthetic resins, celluloid, lampblack, smokeless powder, naphthalene sulfonates, polyethylene naphthalene, wetting agents and dispersants in paints and coatings, and in the manufacture of solvents used in lubricants and in motor fuels (Mason 1995, Lacson, 2000 and O'neil et al., 2001). It is also used in the production of naphthalene ball (moth ball), toilet deodorant, leather tanning agents and carbaryl (ATSDR toxic substance portal, 2005). Naphthalene exposure to humans may occur due to automobile exhaust, transport and disposal of petroleum products, industrial effluents, refuse burning coal gasification, house-hold products, use of pesticides and insecticides and industrial activity.

Naphthalene induces oxidative stress and damages DNA in macrophages (Bagchi et al., (1988) and acute haemolytic anaemia (Santucci and Shah, 2000). Exposure to naphthalene may prove fatal especially in the patients with glucose-6-phosphate dehydrogenase deficiency (Chugh et al., 1977, Bradberry and Vale, 2014) and in normal human subjects, naphthalene poisoning cause prolonged haemolytic anaemia and methaemoglobinaemia (Kundra et al., 2015) and haemoglobinurea (Chauhan et al., 2014). Gastrointestinal effects, renal effects, respiratory effects, neurological effects, hepatic and ocular effects are some of the systemic effects of naphthalene exposure (US Environmental Protection Agency, 1988, 1995; Ekambaram et al., 2017). Strawinski and Stone (1943), Klausmeier and Strawinski (1957), Arhana and Brown (1981), Grund et al., (1992), Fuenmayor et al., (1998), Manohar and Karegoudar (1995), Tomas-Gollado et al., (2014), (Ghosal et al., 2016), Nimatuzahroh et al., (2017) reported salicylate accumulation during naphthalene degradation by different microorganisms however, Annweiler et al., (2000) and Lin et al., (2010) reported naphthalene degradation by Bacillus $s p$. occurs by different pathway. In this communication, the influence of nitrogen source on the pattern of naphthalene degradation by a Pseudomonas aeruginosa and the enzymes of naphthalene degradation has been investigated and reported.

\section{Materials and Methods}

\section{Chemicals}

Naphthalene, salicylic acid and all the inorganic chemicals used for the preparation of medium were purchased from SD Fine chemicals, India. Organic solvents used in this study were obtained from Spectrochem India. 1,2-dihydroxynaphthalene and catechol were procured from Sigma-Aldrich and methanol from J. T. Baker.

\section{Media, microorganism and growth condition}

The mineral-salts medium used in the present investigation contained $\mathrm{g} \mathrm{L}^{-1}$ of following 
constituents $\quad 0.38, \quad \mathrm{~K}_{2} \mathrm{HPO}_{4} ; \quad 0.2$, $\mathrm{MgSO} 4.7 \mathrm{H}_{2} \mathrm{O} ; 0.1, \mathrm{FeSO}_{4} .2 \mathrm{H}_{2} \mathrm{O} ; 0.05$ and 1 , $\mathrm{NH}_{4} \mathrm{Cl}$ or $\mathrm{KNO}_{3}$ as ammonical or nitrate nitrogen source. The $\mathrm{pH}$ of the medium was adjusted to 7 . The medium was supplemented by 10 to $20 \mathrm{mM}$ naphthalene (dissolved in minimal acetone) as specific and sole carbon source.

A naphthalene-degrading bacterium was isolated from a diesel-contaminated site (Arasikere, Hassan District, Karnataka, India) by enrichment culture technique in a mineralsalts medium $\mathrm{gL}^{-1}$ contained 6.3, $\mathrm{K}_{2} \mathrm{HPO}_{4}$; $1.8, \mathrm{KH}_{2} \mathrm{PO}_{4} ; 1, \mathrm{NH}_{4} \mathrm{NO}_{3} ; 0.1 \mathrm{MgSO}_{4} .7 \mathrm{H}_{2} \mathrm{O}$; $0.1, \mathrm{CaCl}_{2} ; 0.1, \mathrm{FeSO}_{4} ; 0.1 \mathrm{MnSO}_{4}, 0.006$, $\mathrm{NaMoO}_{4}$. The $\mathrm{pH}$ was adjusted to 7 . A- $50 \mathrm{ml}$ of the medium was dispensed in $250 \mathrm{ml}$ conical flask and sterilized by autoclaving at $121^{\circ} \mathrm{C}$ for $15 \mathrm{~min}$. The medium was supplemented by naphthalene $(5 \mathrm{~m} \mathrm{M})$ as sole carbon source and aseptically inoculated by 5 $\mathrm{ml}$ of bacteria-soil suspension. The culture was incubated at $30 \pm 2^{\circ} \mathrm{C}$ in a rotary shaker shaking at $160 \mathrm{rpm}$ for two months. After the appearance of turbidity and colour in the culture medium, the naphthalene degrading ability of the bacterium was stabilized by performing several subcultures over a period of another four months. Further, the naphthalene degrading capacity of the bacterium was increased by gradual increase in the naphthalene levels over a period of four months.

The bacterial culture was isolated by serial dilution followed by standard spread-plate method on mineral-salts agar medium, which was supplemented by naphthalene in the form of vapours. The pure bacterial colonies were picked and aseptically inoculated on naphthalene-mineral-salts agar plates and the culture plates were incubated for 24 to $48 \mathrm{~h}$ in bacteriological incubator at $30 \pm 2^{\circ} \mathrm{C}$. Based on Gram staining, biochemical investigations and $16 \mathrm{~S}$ r-RNA partial gene sequencing, the isolated naphthalene-degrading bacterial culture was identified as Pseudomonas aeruginosa.

For studying naphthalene degradation, the bacterium was sub-cultured in $250 \mathrm{ml}$ Erlenmeyer's flasks containing $50 \mathrm{ml}$ of minimal-salts medium containing either $\mathrm{NH}_{4} \mathrm{Cl}$ as ammonical $\left(\mathrm{NH}_{4}{ }^{+}\right)$or $\mathrm{KNO}_{3}\left(\mathrm{NO}_{3}{ }^{-}\right)$ as nitrate nitrogen source. The medium was supplemented by naphthalene $(10-20 \mathrm{mM})$ and the flasks were incubated on a rotary shaker shaking at $160 \mathrm{rpm}$ at $30 \pm 2^{\circ} \mathrm{C}$. Growth of the bacterium at different time incubations was determined by standard plate-count method on naphthalene-minimal salts agar and also by reading the turbidity of the culture medium at $660 \mathrm{~nm}$.

\section{Analytical methods}

\section{Identification of bacterium}

The genomic DNA was isolated from the naphthalene-utilizing bacterium and the fragment of $16 \mathrm{~S} \mathrm{r-RNA}$ gene was amplified by $27 \mathrm{~F}$ (AGAGGTTGATCMTGGCTCAG) and $1492 \mathrm{R}$ (cggttaccttgt tac gactt) primers in a gradient PCR using template DNA (40 ng), primers $(0.5 \mu \mathrm{M})$, dNTPs $(500 \mu \mathrm{M})$ in Taq buffer containing $\mathrm{MgCl}_{2}(1.5 \mathrm{mM})$ and 1 unit of Taq polymerase. The DNA was amplified for 35 cycles (DNA denatured at $94^{\circ} \mathrm{C}$ for 30 sec. followed by annealing at $50^{\circ} \mathrm{C}$ for $30 \mathrm{sec}$., amplification at $72^{\circ} \mathrm{C}$ for $60 \mathrm{sec}$.) and the PCR product purified $(1500 \mathrm{bp})$ purified. The amplified DNA was sequenced (sequencing primers, 27F AGAGGTTGATCMTGGCTC AG and 1492R CGGTTACCTTGT TAC GACTT) using BDT v3.1 cycle sequencing kit in genetic analyser (3730xl, Applied Biosystems) and consensus sequences of $16 S$ rDNA gene was generated using aligner 6 . The $16 S$ rDNA sequence was subjected to NCBI gene bank database using BLAST. Based on maximum sequence identity score, 
the first ten sequences were selected and aligned using Clustal W. The distance matrix generated and the phylogenetic tree was constructed (Kimura 1980, Kumar et al., 2016, Felsenstein, 1985).

Naphthalene from the culture medium were extracted and analysed by UV-Vis spectrophotometer. The culture medium growing on naphthalene was harvested at different incubation periods and extracted twice with equal volumes of diethyl ether. The ether fraction was concentrated and separated into neutral, acid and phenol fraction (Manohar et al., 1999). The ether from different fractions was evaporated under vacuum (Buchi evaporator) and the residue dissolved in methanol. The neutral extract was separated by TLC (silica gel-G), naphthalene recovered and dissolved in cyclohexane. The naphthalene in the cyclohexane fractions were estimated at $275 \mathrm{~nm}$ in a spectrophotometer. The salicylate accumulated in the culture medium at different incubation periods was estimated by $\mathrm{FeCl}_{3}$ method (Manohar and Karegoudar, 1995). Briefly, a $0.1 \mathrm{ml}$ of freshly prepared aqueous $\mathrm{FeCl}_{3}$ solution $(5 \% \mathrm{w} / \mathrm{v})$ was added to $5 \mathrm{ml}$ of clarified culture medium (centrifuged for $10 \mathrm{~min}$ at $10000 \mathrm{rpm}$ ) and the absorbance of purple colour formed was read at $550 \mathrm{~nm}$ in a spectrophotometer (Elico SL159 uv-vis spectrophotometer). The catechol formed by the bacterial transformation of naphthalene was estimated by the method as described by Barnum (1977).

\section{Metabolite characterization}

The Pseudomonas aeruginosa cultures were grown under naphthalene enrichment in minimal-salts medium containing either $\mathrm{NH}_{4} \mathrm{Cl}$ or $\mathrm{KNO}_{3}$ as nitrogen source and the culture was harvested at different time intervals. The bacterium from the culture medium was separated by centrifugation (10000 rpm, $10 \mathrm{~min}$ and $4^{\circ} \mathrm{C}$ ), the $\mathrm{pH}$ of the used medium was adjusted to 2 and extracted twice by two volumes of diethyl ether. Ether extract was concentrated under vacuum to about $20 \mathrm{ml}$, dried over anhydrous sodium sulphate and filtered. Ether was evaporated and the residue obtained was dissolved in minimum volume of HPLC grade methanol. The metabolites in the extract was analyzed by HPLC (Prominence, Shimadzu) fitted with PDA detector in isocratic mode. A $10 \mu \mathrm{l}$ extract was injected and the metabolites were separated through a chromatographic column (Shim-pack hypersilCLC-8 (M) ODS, $4.6 \mathrm{x}$ $150 \mathrm{~mm}, 5 \mu$ particle size) in isocratic mode using solvent system a) methanol (containing $0.05 \% \mathrm{H}_{3} \mathrm{PO}_{4}$ ) and b) $0.05 \%$ aqueous $\mathrm{H}_{3} \mathrm{PO}_{4}$ (9a:1b) at solvent flow rate of $1 \mathrm{ml} / \mathrm{min}$. The metabolites were also detected by TLC and isolated by preparative TLC using a) benzenemethanol - acetic acid (45:8:8), b) benzenedioxane- acetic acid (90:25:5) and c) benzeneacetic acid- water (125:75:3).

\section{Enzyme assays}

\section{Preparation of cell-free extracts}

Freshly growing, mid-logarithmic phase cells of Pseudomonas aeruginosa from naphthalene-minimal salts medium containing either $\mathrm{NH}_{4} \mathrm{Cl}$ or $\mathrm{KNO}_{3}$ as nitrogen source were harvested by centrifugation for $10 \mathrm{~min}(10000$ $\left.\mathrm{rpm}, 4^{\circ} \mathrm{C}\right)$ and washed by ice-cold Tris- $\mathrm{Cl}$ buffer $(50 \mathrm{mM}, \mathrm{pH} 7.4)$. The bacterial cells suspension $(200 \mathrm{mg} / \mathrm{ml}$ buffer) were sonicated ( $2 \mathrm{sec}$ pulse followed by $5 \mathrm{sec}$. rest) at $0-4^{\circ} \mathrm{C}$ until the absorption decreases by $95 \%$ in a sonicator (Vibra cell, Sonics and materials, USA). The unbroken cells and cell debris removed by centrifugation for $15 \mathrm{~min}$. at $15000 \mathrm{rpm}$ and $4^{\circ} \mathrm{C}$. The supernatant obtained was kept in ice and used as enzyme source. The protein content of the enzyme was estimated by Lowry's method (Lowry et al., 1951).

Naphthalene-1,2-dioxygenase assay was performed by monitoring the decrease in the 
absorption at $340 \mathrm{~nm}$ due to the oxidation of NADH (Dua and Meera, 1981). The assay mixture in a total volume of $3.11 \mathrm{ml}$ contained enzyme $(0.1 \mathrm{mg}$ protein), NADH $(1.5 \mu \mathrm{M})$ in phosphate buffer $(50 \mathrm{mM}, \mathrm{pH} 6.5)$. The $\mathrm{E}_{340}$ $\mathrm{nm}\left(6.22 \times 10^{3}\right.$ MolL-1). The mixture was incubated for 3 min to allow background oxidation of $\mathrm{NADH}$, which otherwise would interfere with assay results. The reaction was initiated by the addition of naphthalene $(1 \mu \mathrm{M}$, dissolved in $0.1 \mathrm{ml} 2$-methoxyethanol). The activity of 1,2-dihydroxynaphthalene dioxygenase was followed by change in the absorption at $331 \mathrm{~nm}$ as suggested by (Kuhm et al., 1991). The assay mixture $(1 \mathrm{ml})$ contained $50 \mu \mathrm{l}$ of acetic acid- sodium hydroxide buffer $(50 \mu \mathrm{M}, \mathrm{pH} 5.5)$ and suitably diluted cell-free extract $(100 \mu \mathrm{g}$ of protein). The reaction was initiated by forcing 1,2dihydroxynaphthalene $(10 \mu \mathrm{l}$, dissolved in tetrahydrofuran) through a $25 \mu \mathrm{l}$ syringe. The molar reaction coefficient $(\varepsilon)$ of $2.60 \mathrm{mM}^{-1}$ $\mathrm{cm}^{-1}$ used to calculate enzyme activity. Salicylaldehyde dehydrogenase (Shamsuzzaman and Barnsley, 1974) was determined by the increase in the absorption at $340 \mathrm{~nm}$. Enzyme assay mixture in a final volume of $3 \mathrm{ml}$ contained buffer $(2.75 \mathrm{ml}$, tetrasodiumpyrophosphate $-\mathrm{HCl}, 20 \mathrm{mM}, \mathrm{pH}$ $8.5)$, cell-free extract ( $0.5 \mathrm{mg}$ protein), NAD $(0.1 \mathrm{ml}, 150 \mathrm{mM})$. The reaction was initiated by the addition of salicylaldehyde $(3 \mathrm{mM}$ aqueous). Salicylate hydroxylase (Shamsuzzaman and Barnsley, 1974) assay was estimated at $340 \mathrm{~nm}$ by measuring the oxidation of $\mathrm{NADH}$ in a reaction mix containing EDTA $(1 \mathrm{mM}), \mathrm{NADH}(147 \mu \mathrm{M})$ and sodium salicylate $(133 \mu \mathrm{M})$ in phosphate buffer (20 mM, pH 7).Catechol-1,2dioxygenase (Hegeman, 1966) activity was measured by following the increase in the absorption at $260 \mathrm{~nm}$ due to the formation of cis, cis-muconic acid in the assay mixture (3 ml) containing catechol $(1 \mu \mathrm{M})$, EDTA (10 $\mu \mathrm{M})$ and suitably diluted enzyme (1 mg protein) and phosphatebuffer $(200 \mu \mathrm{M}, \mathrm{pH} 7)$.
Catechol-2,3-dioxygenase (Fiest and Hegeman, 1969), assay mix $3 \mathrm{ml}$ comprising of $0.5 \mathrm{ml}$ of catechol $(10 \mathrm{mM})$ and $0.1 \mathrm{ml}$ cellfree extract $(0.1 \mathrm{mg}$ protein $)$ in phosphate buffer $(100 \mu \mathrm{M}, \mathrm{pH} 7.5)$. The enzyme reaction was monitored by the increase in absorbance at $375 \mathrm{~nm}$ due to the formation of $\alpha$ hydroxymuconicsemialdehyde. The gentisate1,2-dioxygenase enzyme assay was carried out by the method as described by Crowford et al., (1975).Protocatechuate-3,4-dioxygenase and protocatechuate-4,5-dioxygenase enzymes were assayed by the method McDonald et al., (1954). One unit of enzyme activity was defined as $\mu \mathrm{M}$ substrate converted $\mathrm{min}^{-1} \mathrm{mg}^{-}$ ${ }^{1}$ protein.

\section{Results and Discussion}

A bacterium capable of utilizing naphthalene as sole carbon source was isolated from the soil samples obtained from dieselcontaminated site by enrichment culture technique. The bacterium was cultivated in the mineral-salts medium supplemented by naphthalene as sole carbon source. Based on Gram staining, physicochemical and biochemical studies, $16 S$ r-DNA partial gene sequence homology and molecular phylogenetic analysis, the bacterium was identified as Pseudomonas aeruginosa (Fig. 1) and designated as Pseudomonas aeruginosa TU

The bacterium was shifted to grow in a minimal-salts medium containing $\mathrm{NH}_{4} \mathrm{Cl}$ or $\mathrm{KNO}_{3}$ as nitrogen source and supplemented by naphthalene alone as specific and only carbon source. The bacterium was acclimatized to grow on increasing levels of naphthalene over a period of one year by performing several subcultures. The growth behaviour of Pseudomonas aeruginosa on naphthalene in the minimal-medium containing $\mathrm{NH}_{4} \mathrm{Cl}$ or $\mathrm{KNO}_{3}$ as nitrogen source was studied and the results are presented in Figure 2. 


\section{Growth study}

It is evident from Figure 2 that the growth of the bacterium increased with the increase in the incubation time. In the minimal-salts medium containing ammonical ' $\mathrm{NH}_{4}$ ' nitrogen source and enriched with naphthalene (10 $\mathrm{mM}$ ) as the specific and sole carbon source, the initial bacterial-cell population of $9 \times 10^{5}$ colony-forming units (CFU) $\mathrm{ml}^{-1}$ reached to 3 x $10^{7} \mathrm{CFU} \mathrm{ml}{ }^{-1}, 5 \times 10^{7} \mathrm{CFU} \mathrm{ml}^{-1}$ and $8 \times 10^{7}$ $\mathrm{CFU} \mathrm{ml} \mathrm{m}^{-1}$ at the end of 24, 36 and $48 \mathrm{~h}$ of incubation. Further, even though there was an appearance of turbidity, substrate utilization and metabolism, the viable cell population decreased to $4^{4} \mathrm{CFU} \mathrm{ml}{ }^{-1}$ at $60 \mathrm{~h}$ and ceases to exist after $96 \mathrm{~h}$ of incubation. The utilization of naphthalene by the bacterium has resulted in the decrease in the $\mathrm{pH}$ of the culture medium amended with $\mathrm{NH}_{4}{ }^{+}$as nitrogen source, the initial $\mathrm{pH} 7$ of the culture medium decrease to $\mathrm{pH} 5.4$ and 4.3 at the end of 24 and $36 \mathrm{~h}$ and reached to $\mathrm{pH} 3.8$ after $48 \mathrm{~h}$ of incubation (Fig. 2A). The growth of the bacterium in the minimal-salts medium that received nitrate $\left(\mathrm{NO}_{3}{ }^{-}\right)$as nitrogen source and supplemented by naphthalene (10 and $20 \mathrm{mM})$ is depicted in Figure $2 \mathrm{~B}$. The initial cell population of $1.6 \times 10^{6} \mathrm{CFU} \mathrm{ml} \mathrm{m}^{-1}$ in the minimal-salts medium containing $\mathrm{KNO}_{3}$ as nitrate nitrogen source and supplemented by naphthalene $(10 \mathrm{mM})$ as sole carbon source increased to $7 \times 10^{9} \mathrm{CFU} \mathrm{ml}{ }^{-1}$ and $8 \times 10^{9} \mathrm{CFU}$ $\mathrm{ml}^{-1}$ after 24 and $36 \mathrm{~h}$ of incubation. It was also observed that, with the increase in the initial naphthalene to $20 \mathrm{mM}$, the initial cell population of $10^{6} \mathrm{CFU} \mathrm{ml} \mathrm{m}^{-1}$ in the culture medium increased to $9 \times 10^{9}$ to $1 \times 10^{10} \mathrm{CFU}$ $\mathrm{ml}^{-1}$ after 36 and $48 \mathrm{~h}$ of incubation. Naphthalene utilization by the bacterium showed a slight increase in the $\mathrm{pH}$ of the culture medium from $\mathrm{pH} 7$ to $7.4,7.8$ and 8.2 at the end of 24,36 and $48 \mathrm{~h}$ of incubation (Fig. 2B). The culture medium which received $\mathrm{NH}_{4} \mathrm{Cl}$ turned fluorescent yellow where as the one that received $\mathrm{KNO}_{3}$ as nitrogen source turned dark brown. Maximum growth of the bacterium observed between 36 to $40 \mathrm{~h}$ of incubation of bacterium in the minimal-salts medium containing $\mathrm{NH}_{4} \mathrm{NO}_{3}$ as nitrogen source and naphthalene as sole carbon source (Fig. 2C). Naphthalene biodegradation in $\mathrm{NH}_{4} \mathrm{NO}_{3}$ containing medium followed the $\mathrm{NH}_{4} \mathrm{Cl}$ type pattern of naphthalene degradation, wherein, the naphthalene utilization by the bacteria lead to the decrease in the $\mathrm{pH}$ of the culture medium from an initial $\mathrm{pH} 7$ to 5.2 and the maximum viable cell population from an initial $10^{6} \mathrm{CFU} \mathrm{m}{ }^{-1}$ increased to $10^{8} \mathrm{CFU} \mathrm{ml} \mathrm{m}^{-1}$ after 36 to $48 \mathrm{~h}$. Further the cell viability decreased.

\section{Naphthalene utilization}

Studies on the naphthalene utilization by the bacterium in the minimal-salts medium containing ammonical or nitrate nitrogen were conducted and the results are presented in Figure 3. The naphthalene-degrading Pseudomonas aeruginosa when incubated with naphthalene in the minimal-medium containing $\mathrm{NH}_{4} \mathrm{Cl}$ as nitrogen source, could degraded a maximum of $66 \%$ of the initial 10 $\mathrm{mM}$ naphthalene load after $120 \mathrm{~h}$. The results indicate that the 48,54 and $58 \%$ of an initial $10 \mathrm{mM}$ naphthalene in the culture medium was degraded by the bacterium within 24,36 and $48 \mathrm{~h}$ of incubation and there after the degradation of naphthalene slowed down drastically. Contrary to this, the same bacterium showed the complete degradation of initial 10 and $20 \mathrm{mM}$ naphthalene concentrations at the end of 24 and $36 \mathrm{~h}$ respectively in the culture medium that received $\mathrm{KNO}_{3}$ as nitrogen source (Fig. 3).

\section{Estimation of salicylate and catechol}

Naphthalene utilization by the bacterium has resulted in the accumulation of salicylate $(0.58$ $\mathrm{mM})$ and catechol $(24 \mu \mathrm{M})$ after 48 and $36 \mathrm{~h}$ 
respectively as the end products of naphthalene degradation in the culture medium, which received $\mathrm{NH}_{4} \mathrm{Cl}$ as nitrogen source whereas, the culture medium that received $\mathrm{KNO}_{3}$ as nitrogen source, showed 102,74 and $60 \mu \mathrm{M}$ of catechol at the end of 24,36 and $48 \mathrm{~h}$ respectively and a transient accumulation of about $1.1 \mathrm{mM}$ salicylate at 6 to $8 \mathrm{~h}$ which disappeared after $14 \mathrm{~h}$ (Fig. 4).

\section{Metabolite characterization}

The results on the metabolite characterization by TLC are presented in Table 1 . The ether extracts of the spent medium obtained from naphthalene grown culture (36 h), which received $\mathrm{NH}_{4} \mathrm{Cl}$ as nitrogen source showed the presence of salicylic acid and catechol whereas, only catechol as an intermediary metabolite was found in the extracts of the culture medium that contained $\mathrm{KNO}_{3}$ as nitrogen source (Table 1).

The results on the metabolite characterization by HPLC are presented in Figure 5.

The HPLC elution profile of the metabolites showed the presence of 1,2dihydroxynaphthalene, salicylic acid and catechol in the extracts of Pseudomonas aeruginosa culture medium amended with $\mathrm{NH}_{4} \mathrm{Cl}$ as nitrogen source and naphthalene as carbon source whereas, catechol and detectable amount of salicylate was observed in the culture filtrate of the cells grown for 12 $\mathrm{h}$ in the naphthalene minimal-salts medium containing $\mathrm{KNO}_{3}$ as nitrogen source, however, at the end of $24 \mathrm{~h}$ both salicylate and naphthalene disappeared and new metabolites at retention time $\left(\mathrm{t}_{\mathrm{R}}\right) 1.7,2.6,2.9$ and 4.34 appeared.

\section{Enzyme investigations}

The results on the enzyme investigations in the crude cell-free extracts of Pseudomonas aeruginosa TU grown in naphthalene-minimal salts medium containing ammonical or nitrate nitrogen source are shown in Table 2.

It is evident from the results presented in Table 2, that the cell-free extracts of the naphthalene grown cells showed the activities of all the above enzymes tested except for that of gentisate dioxygenase and protocatechuate dioxygenases. The results suggest that the cell-free extracts of the naphthalene-grown cells of $P$. aeruginosa TU in the presence of $\mathrm{KNO}_{3}$ as nitrogen source, exhibited higher activities of all the naphthalene-degrading enzymes as it is compared to that of the enzyme activities in the cell-free extract grown in $\mathrm{NH}_{4} \mathrm{Cl}$ containing medium.

Table.1 $\mathrm{R}_{\mathrm{f}}$ values and $K_{\max }$ of metabolites isolated from cultures filtrates of naphthalene grown cells

\begin{tabular}{|l|c|c|c|c|c|c|c|c|}
\hline \multirow{2}{*}{ Compound } & \multicolumn{2}{|c|}{ A } & \multicolumn{2}{c|}{ B } & \multicolumn{2}{c|}{ C } & \multicolumn{2}{c|}{$\boldsymbol{\Lambda}_{\max }$} \\
\cline { 2 - 10 } & $\mathrm{a}$ & $\mathrm{b}$ & $\mathrm{a}$ & $\mathrm{b}$ & $\mathrm{a}$ & $\mathrm{b}$ & $\mathrm{a}$ & $\mathrm{b}$ \\
\hline Salicylic acid & 0.82 & $0.81^{\mathrm{N}}$ & 0.71 & $0.71^{\mathrm{N}}$ & 0.72 & $0.72^{\mathrm{N}}$ & 234,296 & 234,296 \\
\hline Catechol & 0.7 & $0.7^{\mathrm{N}}$ & 0.63 & $0.63^{\mathrm{N}}$ & 0.69 & $0.69^{\mathrm{N}}$ & 276 & $276^{\mathrm{N}}$ \\
\hline Salicylic acid & 0.81 & $\mathrm{ND}^{\mathrm{K}}$ & 0.71 & $\mathrm{ND}^{\mathrm{K}}$ & 0.72 & $\mathrm{ND}^{\mathrm{K}}$ & 234,296 & $\mathrm{ND}^{\mathrm{K}}$ \\
\hline Catechol & 0.71 & $0.7^{\mathrm{K}}$ & 0.63 & $0.64^{\mathrm{K}}$ & 0.69 & $0.69^{\mathrm{K}}$ & 276 & $276^{\mathrm{K}}$ \\
\hline
\end{tabular}


Table.2 Specific activities of naphthalene metabolizing enzymes in the cell-free extracts of Pseudomonas aeruginosa TU grown in minimal-salts medium containing $\mathrm{NH}_{4} \mathrm{Cl}$ or $\mathrm{KNO}_{3}$ as nitrogen source and supplemented by naphthalene as sole carbon source

\begin{tabular}{|l|c|c|c|c|c|c|c|}
\hline \multirow{2}{*}{ Growth substrate } & \multicolumn{5}{|c|}{ Specific activities of enzymes in crude cell-free extracts } \\
\cline { 2 - 8 } & NDO & $1,2-$ DHNDO & SALDDH & SALH & C1,2O & C2,3O & GDO \\
\hline Naphthalene + $\mathbf{N H}_{\mathbf{4}} \mathbf{C l}$ & 0.38 & 3.2 & 1.2 & 0.18 & 0.03 & 0.12 & ND \\
\hline Naphthalene + $\mathbf{K N O}_{3}$ & 0.82 & 4.9 & 2.2 & 0.6 & 0.05 & 0.42 & ND \\
\hline Glucose & ND & ND & 0.1 & ND & 0.04 & ND & ND \\
\hline
\end{tabular}

NDO- naphthalene dioxygenase, 1,2-DHNDO- 1,2-Dihydroxynaphthalene dioxygenase, SALDDH-salicylaldehyde dehydrogenase, SALH-salicylate hydroxylase, C1,2O-catechol-1,2-dioxygenase, C2,3O-catechol-2,3-dioxygenase, GDO-gentisate dioxygenase. ND-not detected

Figure.1 Molecular phylogenitic analysis of $16 S$ r-RNA partial gene-sequence

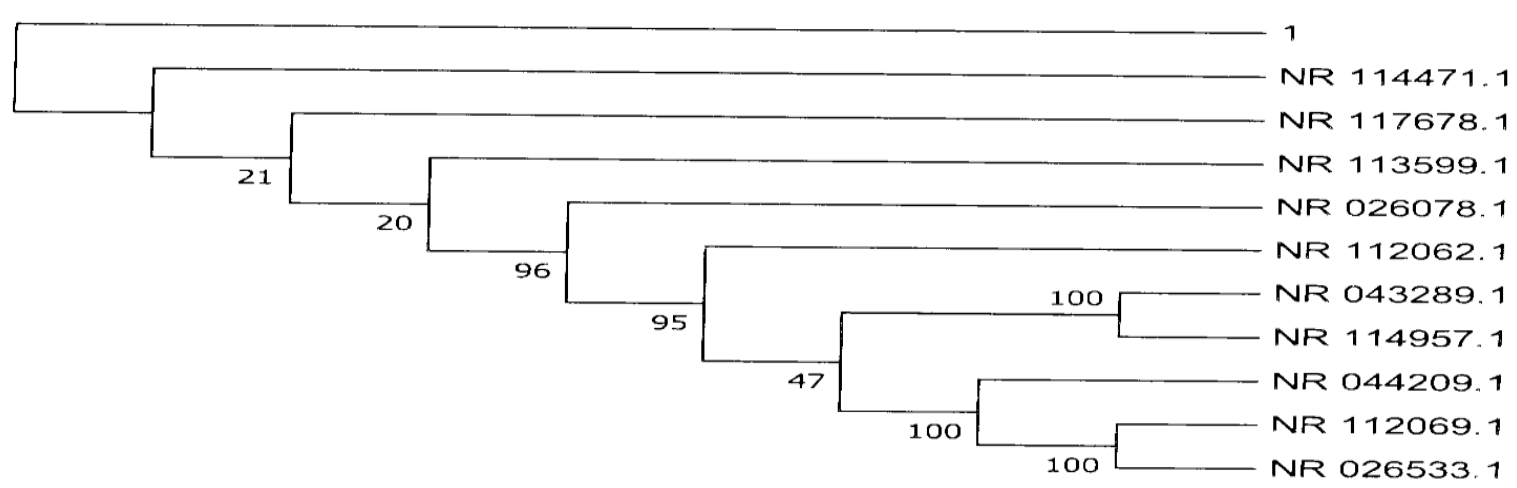

Figure.2 Growth of Pseudomonas aeruginosa TU on naphthalene in the minimal-salts medium containing $\mathrm{NH}_{4} \mathrm{Cl}(\mathrm{A})$ and $\mathrm{KNO}_{3}(\mathrm{~B})$ and the change in $\mathrm{pH}$ of the culture medium.

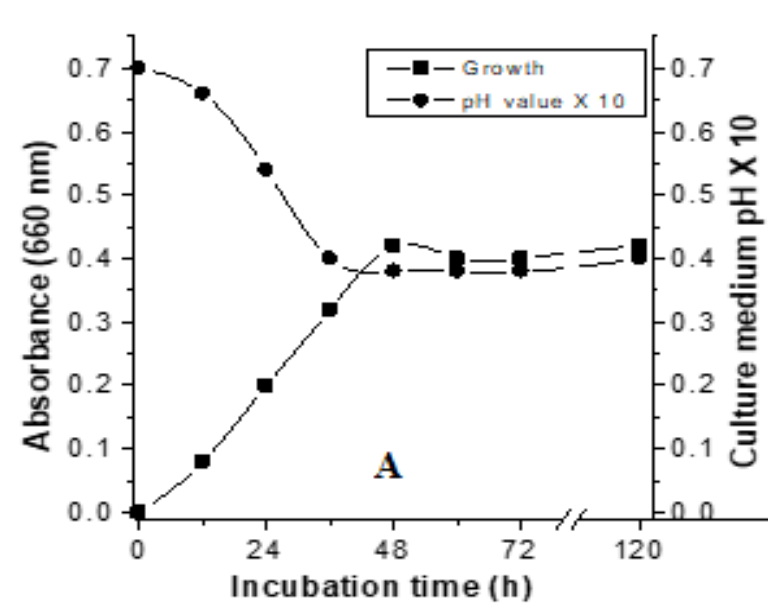

Incubation time (h)

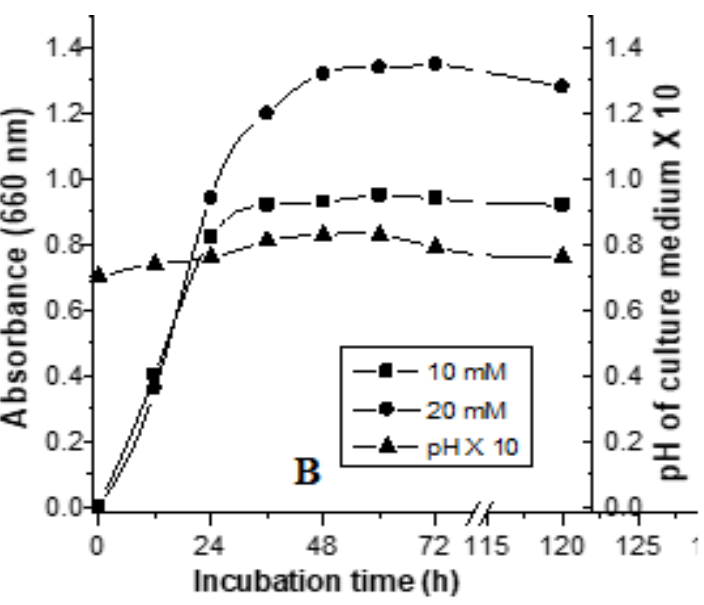


Figure.3 Time dependent utilization of naphthalene by the bacterium in the minimal-salts medium containing $\mathrm{NH}_{4} \mathrm{Cl}$ and $\mathrm{KNO}_{3}$ as nitrogen source
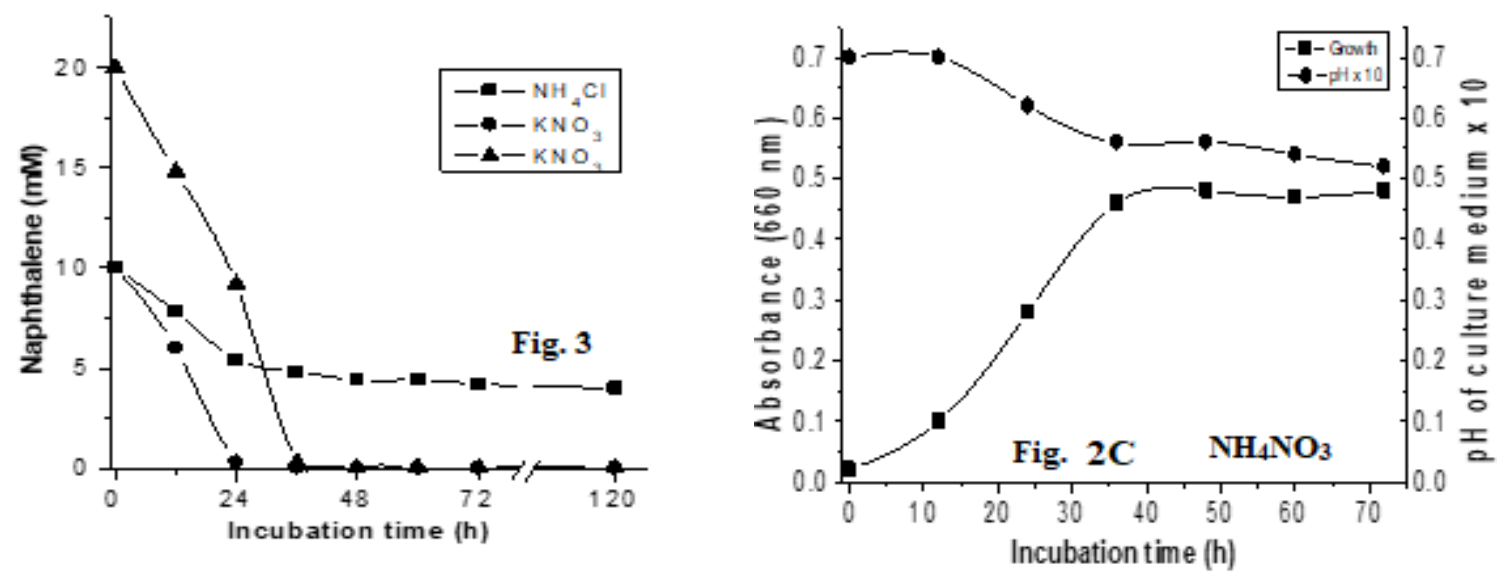

Figure.4 Biotransformation of salicylic acid and catechol from naphthalene by a Pseudomonas aeruginosa $\mathrm{TU}$ in the culture medium containing $\mathrm{NH}_{4} \mathrm{Cl}$ and $\mathrm{KNO}_{3}$ as nitrogen source
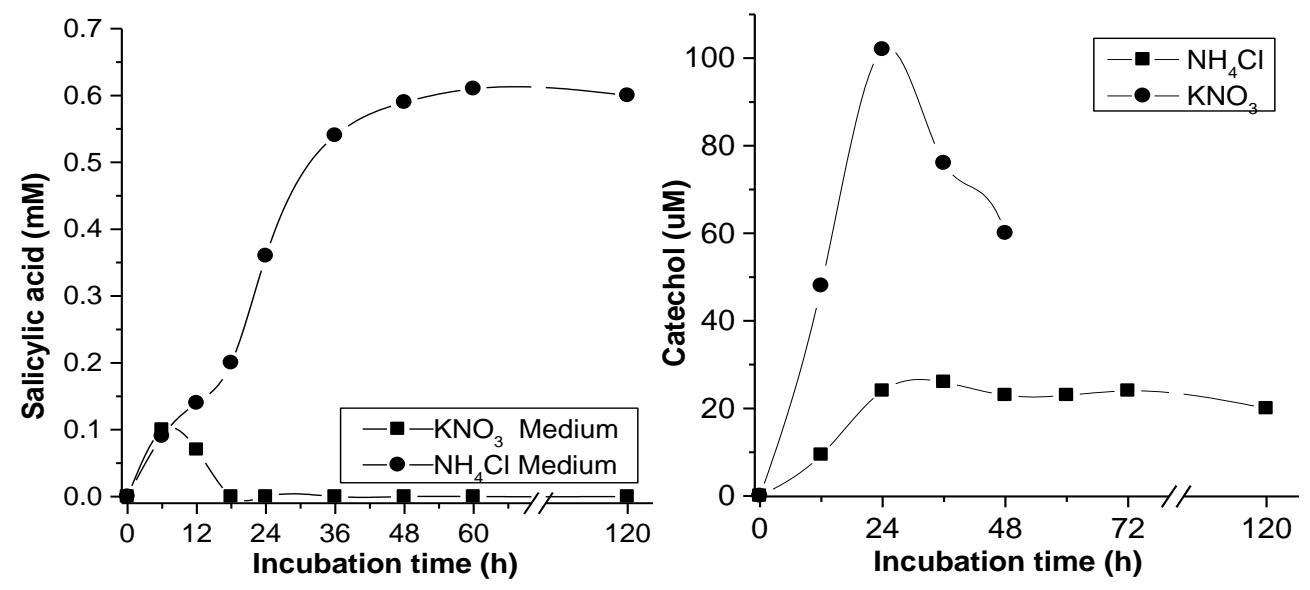

Figure.5 HPLC elution profile of the metabolites extracted from the cultures of naphthalene grown cells of Pseudomonas aeruginosa $\mathrm{TU}$ in the medium containing $\mathrm{NH}_{4} \mathrm{Cl}-\mathrm{A}-$ and $\mathrm{KNO}_{3}-\mathrm{B}$ and $\mathrm{C}$

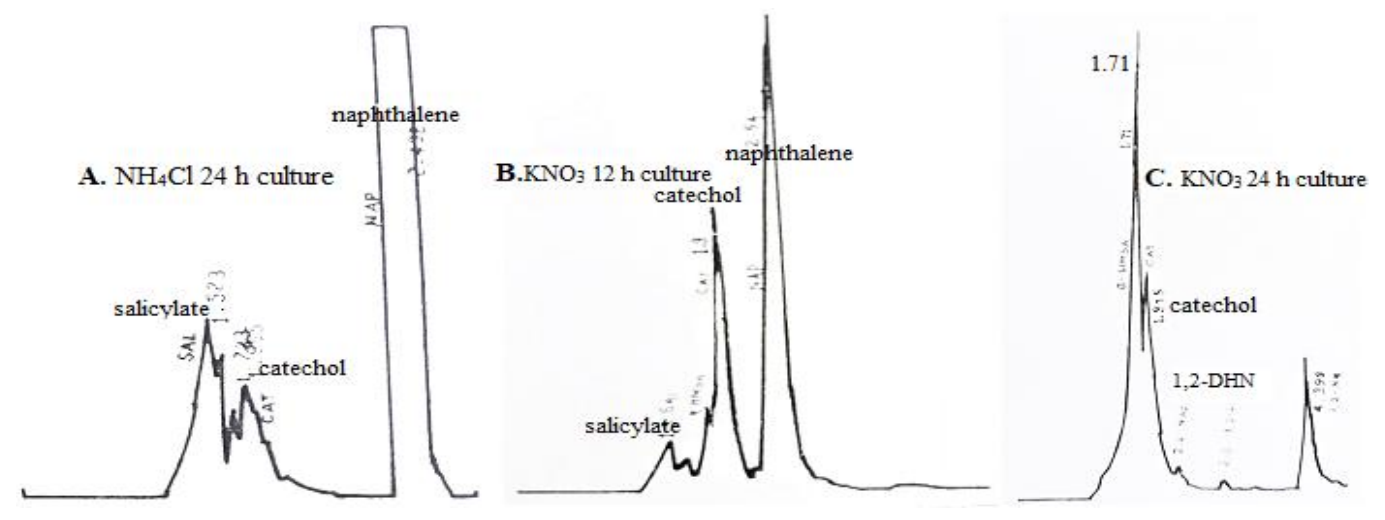


It is evident from the results presented in Figure 2 and 3 that the Pseudomonas aeruginosa TU showed better growth and naphthalene degradation in the medium containing $\mathrm{KNO}_{3}$ as nitrogen source as it is compared to that of the medium amended with $\mathrm{NH}_{4} \mathrm{Cl}$ as nitrogen source. In the minimal-medium containing $\mathrm{NH}_{4} \mathrm{Cl}$ as nitrogen source, bacterium could degrade only $66 \%$ of an initial $10 \mathrm{mM}$ naphthalene further, naphthalene degradation by bacterium was accompanied by the concomitant accumulation of salicylate $(0.63 \mathrm{mM})$ in the culture medium, which may have decrease in the $\mathrm{pH}$ of the culture medium from 7 to 3.8 . The accumulation of salicylate, catechol (Fig. 3 and 5) and other phenolic products in the culture medium during naphthalene degradation may have slowed bacterial growth, which may have resulted in loss in cell viability (Aranhaand Brown, 1981; Manohar and Karegoudar, 1995). Contrary to this, in the present investigation, the same bacterium degraded 10 and $20 \mathrm{mM}$ initial naphthalene within 24 and $36 \mathrm{~h}$ of incubation in the minimal-medium containing $\mathrm{KNO}_{3}$ as nitrogen source, interestingly, there was an increase in the $\mathrm{pH}$ of the culture medium from $\mathrm{pH} 7$ to 8.2. Such observations were made by Aranha and Brown (1981) and reported slight change in $\mathrm{pH}$ of the culture medium from 7 to 7.3 after $48 \mathrm{~h}$ of growth. In the present investigation, we have made an observation that the minimal-salts medium amended with $\mathrm{KNO}_{3}$ as nitrogen source supported better and uniform growth of the bacterium as compared to the growth in $\mathrm{NH}_{4} \mathrm{Cl}$ containing medium. The bacterial growth in naphthalene minimalmedium containing ammonical nitrogen source slowed, cells occluded and lost viability within 4 days. Majority of the studies on naphthalene degradation by various bacterial species have been conducted using ' $\mathrm{NH}_{4}{ }^{+}$' as ammonical nitrogen source (Strawinski and Stone, 1943; Klausmeier and Strawinski, 1957; Shamsuzzaman and
Barnsley, 1974; Dua and Meera, 1981; Grund et al., 1992; Fuenmayor et al., 1998; Manohar and Karegoudar, 1995; Tomas-Gollado et al., 2014; Ghosal et al., 2016; Nimatuzahroh et $a l$. , 2017) and reported the production of salicylate in the medium but, none of the investigations reported decrease in $\mathrm{pH}$ of the culture medium. Aranha and Brown (1981) reported salicylate and the decrease in $\mathrm{pH}$ of the culture medium containing $\mathrm{NH}_{4} \mathrm{Cl}$ as nitrogen source and suggested $\mathrm{pH}$ remains stable in the culture medium containing $\mathrm{KNO}_{3}$. We have observed that the degradation of naphthalene by the Pseudomonas aeruginosa TU occurs via salicylate and catechol in both $\mathrm{NH}_{4} \mathrm{Cl}$ and $\mathrm{KNO}_{3}$ containing medium but, interestingly just detectable levels of salicylate accumulates transiently at the early growth phase (6 to $14 \mathrm{~h}$ ) in $\mathrm{KNO}_{3}$ containing medium and after 36 to $48 \mathrm{~h}$ the $\mathrm{pH}$ increases to 8.3 whereas, high levels of salicylate builds up in $\mathrm{NH}_{4} \mathrm{Cl}$ containing culture medium and subsequently the $\mathrm{pH}$ decreases to 3.8 at the end of $48 \mathrm{~h}$. The higher activities of the enzymes upstream to salicylate hydroxylase and low activities of salicylate hydroxylase and catechol oxygenases in the cell-free extracts of bacterium grown in the medium containing $\mathrm{NH}_{4} \mathrm{Cl}$ supports the possible accumulation of salicylate in the culture medium as compared to the enzyme activities observed in the cellfree extracts of cells grown on naphthalene in mineral salts medium containing $\mathrm{KNO}_{3}$. Since naphthalene, a possible carcinogen, is found naturally in the environment and also used as starting material in various industrial processes (Mason 1995, Lacson, 2000 and O'neil et al., 2001), human exposure may occur by both natural and anthropogenic activities (Paterson and Kodukala, 1981; Jacob et al., 1986) thus, its effective bioremediation is the only strategy to clean up the environment, which needs understanding of the optimal conditions for bioremediation process is prerequisite. The outcome of the 
present investigations may aid in developing bioremediation technology for toxic PAHs and their derivatives from industrial effluents and contaminated sites.

\section{Acknowledgement}

Authors thank Tumkur University for providing laboratory facilities and Gulbarga university for extending the equipment and laboratory facility for conducting enzyme assays.

\section{References}

Annweiler, E.,Richnow, H. H.,Antranikian, G., Hebenbrock, S., Garms, C.,Franke, S., Francke, W., and Michaelis, W. 2000. Naphthalene degradation and incorporation of naphthalene derived carbon into biomass by the thermophile Bacillus thermoleovorans. Appl. Environ. Microbiol. 66(2): 518-52

Aranha, H. G., and Brown, L. R. 1981. Effect of nitrogen source on end products of naphthalene degradation. Appl. Environ. Microbiol 42 (1): 74-78

ASTDR toxic substance portal (2005) Public health statement for naphthalene, 1methylnaphthalene and 2-methyl naphthalene CAS\#: 91-20-3, 90-120and 91-57-6

Bagchi, M., Bagchi, D., Balmoori, J., Ye, X., Stohs, S. J. 1988. Naphthalene induces oxidative stress and DNA damage in cultured macrophage J744A.1 cells. Free RadicBiol Med. 25:137-43.

Bamforth, S. M., and Singleton, I. 2005. Bioremediation of polycyclic aromatic hydrocarbons: current knowledge and future directions. J. Chem. Technol. Biotechnol. 80: 723-36

Barnum, D. W. 1977. Spectrophotometric detection of catechol, epinephrine, dopa, dopamine and other aromatic vicdiols. AnalyticaChemicaActa. 89 (1):
157-66

Bradberry, S. M., and Vale, J. A. 2014. Oxford desk ref: Toxicology. $1^{\text {st }}$ Ed. Naphthalene and p-dichlorobenzene. In: Bateman N, Jefferson R, Thomas S, Thompson J \& Vale A; Pp. 254

Cerniglia, C.E. 1993. Biodegradation of polycyclic aromatic hydrocarbons. Curr. Opin. Biotechnol. 4:331-338

Chouhan, V., Sharma, R., Sharma, K., Sharma, G., Jitender, S., and Jearth, V. 2014Toxicol. Int. 21(3):314-15

Chugh, K. S., Singhal, P. C., Sharma, B. K. 1977. Acute renal failure due to in north Indian patients. Am. J. Med. Sci. 274:139-46.

Daane, L. L., Harjono, I., Zylstra, G. J., and Haggblom, M. M. 2001. Isolation and characterization of polycyclic aromatic hydrocarbon-degrading bacteria associated with the rhizosphere of salt marsh plants. Appl. Environ. Microbiol. 67(6): 2683-2691

Dua, R. D., and Meera, S. 1981. Purification and characterization of naphthalene oxygenase from Corynebacterium renale. Eur. J. Biochem. 12:461

Ekambaram, S., Chandan Kumar, K. M., Mahalingam, V. 2017. Acute kidney injury: a rare complication of mothball poisoning. Saudi J Kidney Dis Transpl. 28(6): 1412-15

EPA health effects note book for hazardous air pollutants- draft EPA- 452/D-95-00, PB95-503579, December 1995. Available at http://www.epa.gov/ttn/ atw/hapindex.html).

Felsenstein, J. 1985. Confidence limits on phylogenies: An approach using the bootstrap. Evolution 39:783-791.

Fuenmayor, S. L., Wild, M., Boyes, A. L., and Williams, P. A. 1998. A gene cluster encoding steps in conversion of naphthalene to gentisate in Pseudomonas sp. strain U2. J. Bacteriol 180(9): 2522-30 
Gervais, J., Luukinen, B., Bhul, K., and Stone, D. 2010. Naphthalene general fact sheet. National pesticide information centre, Oregon State University Extension service. npic.orst. edu.

Ghosal, D., Ghosh, S., Dutta, T. K., and Ahn., Y. 2016. Current State of Knowledge in Microbial Degradation of Polycyclic Aromatic Hydrocarbons (PAHs): A Review. Frontiers in Microbiology. 7: 1369.

Grund E, Denecke B and Eichenlaub R (1992) Naphthalene degradation via salicylate and gentisate by Rhodococus $s p$. strain B4. Appl. Environ. Microbiol. 58 (6): 1874-77.

Health and environmental effects profile, naphthalene EPA/600/X-82/241. Cincinnati $(\mathrm{OH})$ : Environmental criterion and assessment office, Office of the health and Environmental Assessment, Office of Research and Development; 1988.

Jacob,J., Karcher, W., Belliardo, J.J., Wagstaffe, P.J. 1986. Polycyclic aromatic hydrocarbons of environmental and occupational importance. Fresen. Z. Anal. Chem. 323:1

Kimura, M. 1980. A simple method for estimating evolutionary rate of base substitutions through comparative studies of nucleotide sequences. J. Molecular Evolution 16:111-120.

Klausmeier, R. E., and Strawinski, R. J. 1957. Microbial oxidation of naphthalene. I. Factors concerning salicylate accumulation. J. Bacteriol. 73:461-464.

Kuhm, A. E., Stolz, A. Ngai, K., and Knackmuss H. J. 1991. Purification and characterization of a 1,2dihydroxynaphthalene dioxygenase from a bacterium That degrades naphthalenesulfonic acids. J. Bacteriol. 173 (12):3795-3802.
Kumar. S., Stecher, G., and Tamura. K. 2016. MEGA7: Molecular Evolutionary Genetics Analysis version 7.0 for bigger datasets. Molecular Biology and Evolution. 33(7): 1870.

Kundra, T. S., Bhutatani, V., Gupta, R., and Kaur, P. 2015. Naphthalene poisoning following ingestion of moth balls: A case report J. Clin. Diag. Res. 9(8): UDO1-UDO2.

Lacson, J. G. 2000. CEH Product ReviewNaphthalene, Menlo park, CA, Chemical Economics Handbook (CEH)SRI International.

Laflamme, R. E., and Hites, R. A. 1978.The global distribution of polycyclic aromatic hydrocarbons in recent sediments. Geochim. Cosmochim. Akta. 42: 289-303.

Lin, C., Gan, L., and Liang-Chen, Z. 2010. Biodegradation of naphthalene by strain Bacillus fusiformis (BFN) J. Hazardous Material 182: 771-77.

Lotufo, G. R. 1998. Bioaccumulation of sediment-associated fluoranthene in benthic copepods: uptake, elimination and biotransformation. Aquat. Toxicol. 44:1-15.

Lowry, O. H., Rosebrough, N. J., Farr, A. L., and Randall, R. J. 1951.Protein measurement with the Folin-phenol reagent. J. Biol. Chem. 193: 265.J. Biol. Chem. 192: 265.

Manohar, S., and Karegoudar, T. B. (1995) Degradation of naphthalene by a Pseudomonas strain NGK1. Indian $\mathbf{J}$ Exptl. Biol.31:351-56

Manohar, S., Kim, C.K., and Karegoudar, T.B. 1999. Degradation of anthracene by a Pseudomonas sp. strain NGK1 J. Microbiology 37(2):73-79.

Mason, R. T. 1995. Naphthalene. In: Kroschwitz J L and Hpwe-Grant M Eds Kirk-OthomerEncyclopedia of Chemical Technology. $4^{\text {th }}$ Ed. Vol.16, N Y John Wiley \& Sons: 963-979. 
Mc Donald, D. L., Stainer, R.Y., and Ingraham, J. L. 1954. J. Biol. Chem. 210:809.

Menzie, C. A., Potocki, B. B., and Santodonato, J. 1992. Exposure to carcinogenic PAHs in the environment. Environ. Sci. Technol. 26:1278-1284.

Nimatuzahroh, Trikurniadewi, N., Pramadita, A. R. A., Pratiwi, I. A., Salamun, Fatimah and Sumarshi, S, 2017 Biodegradation of naphthalene and phenanthrene by a Bacillus subtilis 3KP. AIP conference proceedings 1854 , 020026. https://doi.org/10.1063/ 1.4985417.

Patterson, J. W., andKodukala1981. Biodegradation of hazardous organic pollutants CEP 48.

Santucci, K., and Shah, B. 2000. Association of naphthalene with acute haemolytic anaemia. Acad. Emerg. Med. 7:42-7.
Strawinski, R.J., and Stone, R. W. 1943. Conditions governing the oxidation of naphthalene and the chemical analysis of its product. J. Bacteriol. 45:16.

Sutherland, J. B., Rafii, F., Khan, A. A., and Cerniglia, C. E. 1995. Mechanisms of polycyclic aromatic hydrocarbon degradation, p. 269-306. In L. Y. Young and C. E. Cerniglia (ed.), Microbial transformation and degradation of toxic organic chemicals. John Wiley and Sons, Inc., New York, N.Y.

Tomás-Gallardo, L., Gómez-Álvarez, H., Santero, E., and Floriano, B. 2014. Combination of degradation pathways for naphthalene utilization in Rhodococcus sp. strain TFB. Microbial Biotechnology 7(2): 100-113.

\section{How to cite this article:}

Savitha, K.R., T.N. Shamu, Lalitha Junna and Manohar Shinde. 2019. Influence of Nitrogen Source on the Catabolism of Naphthalene by a Pseudomonas aeruginosa TU. Int.J.Curr.Microbiol.App.Sci. 8(10): 947-959. doi: https://doi.org/10.20546/ijcmas.2019.810.111 